\title{
Chapter 1 \\ The Making of Racial and Ethnic Categories: Official Statistics Reconsidered
}

\author{
Patrick Simon, Victor Piché, and Amélie A. Gagnon
}

\subsection{Introduction}

One of the most striking features of the end of the twentieth century was the resurgence of the ethnic question in public debates, both in developing and in developed countries. Between conflicts and wars interpreted from an ethnic perspective (the Balkans and central Africa), nationalist struggles (the Basque country, Quebec and Belgium), and demands for recognition and political representation by new ethnic minorities resulting from immigration, every country is currently affected by what is commonly known as cultural pluralism (Hobsbawm 1993; Dieckhoff 2000; Faist 2009; Simon and Piché 2013). This 'ethnic renewal', to coin the expression used to qualify the growing interest for ethnic diversity in the 1960s in the US, is not only driven by a sort of obsession for cultural differences as an explanation for all kinds of social and political phenomenon. It derives from different legacies: from the increasing diversity of the population of countries that have undergone large immigration flows to the long lasting cohabitation of national minorities within modern Nation states, from the history of slavery to the post-colonial era. This

\footnotetext{
P. Simon $(\bowtie)$

International Migration and Minorities Unit, Institut National d'Etudes

Démographiques, 133 Boulevard Davout, 75020 Paris, France

e-mail: simon@ined.fr

V. Piché

Oppenheimer Chair in Public International Law,

McGill University and Honorary, University of Montreal,

Melrose 2249, H4A 2R7 Montreal, Canada

e-mail: v-pic@hotmail.com
}

\author{
A.A. Gagnon \\ Institute for Statistics, UNESCO, \\ Montreal, Canada \\ e-mail: a.gagnon@uis.unesco.org
}


resurgence or extension of the salience of ethnicity in most of the societies around the world can be found not only in public discourses, policy-making, scientific literature and popular representations, but also in the pivotal realm of statistics. Indeed, at the turn of century, an increasing number of countries are processing routinely data on ethnicity or race of their population. This is precisely what this book is about: ethnic and racial classifications in official statistics, as a reflection of the representations of population and an interpretation of social dynamics through different lenses.

The use of ethnic categories is not without problems, and a growing literature discusses the issue of the social and political significance of such categories (see for instance Anderson and Fienberg 1999; Zuberi 2001; Szreter et al. 2004; Rallu et al. 2006; Brubaker 2009; Williams and Husk 2012). The linkages between political framings and the statistical categories that support them can be observed in every society (Nobles 2000). Population statistics are indeed not only aiming at producing knowledge of demographic dynamics, they provide a benchmark for policies and contribute to the production and reproduction of national identity (Desrosières 1993; Alonso and Starr 1987; Anderson 1991). Official and scientific statistical categorisations reflect and affect the structural divisions of societies, as well as mainstream social representations. As conventions, they offer arbitrary definitions of the social objects they are intended to describe, but these definitions ensue from historical, social and political processes of negotiations between public authorities and social forces. In this respect, censuses are a strategic place in which views on race and ethnicity are confronted by official statistics. In this sense, censuses do more than reflect social realities; they also participate in the construction of these realities (Kertzer and Arel 2002, p. 1).

What type of data on ethnicity and/or race are processed, using which definitions and for which purposes are they collected are questions of a crucial importance. In order to highlight the challenges related to 'ethnic statistics', the book is organized around three main issues. In the first part, ethnic enumeration and systems of classification are shown to vary considerably from one society to another. Two chapters, in attempting to answer such questions as 'who counts' and 'for what purpose', offer a comparative and global perspective on the production and use of ethnic statistics. In the second part, the link between enumeration and identity politics is highlighted through a series of case studies dealing with France, Québec (Canada), Brazil and Great Britain. Finally, as mentioned above, measuring ethnicity and race poses tremendous challenges and the third part of the book, in examining some of the problems involved in measurement issues and the solutions implemented in different countries. The chapters argue that measurement issues are not technical in nature but are linked to competing claims within societies. Case studies include discussions of Malaysia, Uruguay, Belgium, Mexico and Canada. ${ }^{1}$

\footnotetext{
${ }^{1}$ All chapters except Chaps. 5 and 7 are revised papers presented at the International Conference on Social Statistics, organized jointly by the CIQSS and INED in 2007. For other case studies focused on competing claims, see Simon and Piché (2013).
} 


\subsection{Comparative Accounts of Ethnic Statistics}

Statistical constructions around ethnic categories cover a wide diversity of situations across state boundaries, which make any attempt at generalization difficult. This is essentially owing to historical and social specificities and the political dynamics that shape racial and/or ethnic stratification. Conquests, annexations, redefinition of borders, or migration have placed certain groups in minority positions, whether they are old or recent minorities. Looking at the wide variety of practices of ethnic and racial categorizations in time and space, we have suggested elsewhere a basic but yet comprehensive typology of types of 'data collection regimes' (Rallu et al. 2006). Six cases were identified. The first two cases reflect the situation where ethnicity is not part of the official statistical production (labelled here not counting in the name of national integration or in the name of multiculturalism). The first type is associated with the nation-building process in which homogenization of population is conceived as a condition for national cohesion (Gellner 1983; Hobsbawm 1990). According to the so-called republican perspective, ethnic 'particularisms' are downplayed as undesirable markers of fragmentation and should disappear through an unavoidable assimilation process, or should be kept in the unofficial representation of the society. Ethnic categories are therefore avoided in statistics for the same reason than ethnic communities are perceived to threaten the cohesion of the national society. The second case (not counting in the name of multiculturalism) seems contradictory since it is associated with not counting for reasons that have little to do with racist views or national unification, but rather with a positive value of cultural mixing and multiculturalism.

The four following types involve counting (i.e., ethnicity is part of national statistics) for different reasons. The third case (counting to dominate) has characterized a major part of historical experiences associated with ethno-cultural supremacy, colonialism and imperialism. Although very widespread in the past, it still exists in some newly independent countries and neo-imperial states. The fourth case (counting in the name of multiculturalism) is the mirror image of the second case above whereby counting is associated with an appreciation of cultural mixing. The fifth case (counting for survival) refers to 'threatened' national minorities using ethnic statistics to demand more power enabling them to maintain their cultural specificity. Finally, the sixth case (counting to justify positive action) has appeared recently and implies a complete reversal of the racist and discriminatory perspective characterizing the third case above. Even if the categories may have been produced in a different context, and to serve opposite purposes, data collection is embedded in a broader equality policy (Simon 2005). Classifications are thus defined by equality laws to fit with legal or semi-legal standards describing protected minorities.

This typology should not be used in a unilateral mode. Different types of rationales and uses can be found simultaneously in the same country or sequentially according to historical contexts. However, the typology does convey a sense of diversity, which is illustrated in Chaps. 2 and 3. Ann Morning's chapter on ethnic classification in a global perspective presents a cross-national survey of the 2000 
census round. This chapter draws on a global data set compiled by the United Nations Statistical Division to survey the approaches to ethnic enumeration taken in 138 countries. Thirty seven percent of the countries surveyed forgo ethnic enumeration ('do not count') for reasons associated with national unity. On the other hand, $63 \%$ of the national censuses studied incorporate some form of ethnic enumeration, but their question and answer formats vary along several dimensions that betray diverse conceptualizations of ethnicity (for example, as 'race' or 'nationality'). Moreover, these formats follow notably regional patterns. The nations of the Americas are most likely to field census questions regarding ethnicity, while European and African states are much less likely to do so. Among those doing so, 'ethnicity' is generally the preferred term, but 'nationality' (distinct from citizenship) is frequently used in European censuses, queries about indigenous status appear regularly on South and Central American censuses, and 'race' is sharply limited to the former slave societies of the Americas and their territories. Despite the diversity of approaches to ethnic enumeration, Ann Morning concludes that they can be grouped into a basic taxonomy of classification schema, as is suggested by Rallu et al. (2006), implying greater commonality in worldwide manifestations of the ethnicity concept than some have recognized.

Tahu Kukutai and Victor Thompson (Chap. 3) argue in their chapter on 'the politics of enumerating the Nation' that ethnic enumeration practices are framed as the by-products of parochial and socio-political contexts influenced by inter-group relations. As a result, systematic patterns in the concepts and categories that states use for racial and ethnic enumeration within and across state boundaries are left unexplained. Their chapter compares and empirically tests two perspectives for understanding national ethnic enumeration practices in a global context. First, they evaluate the responsiveness of nation-states to external pressures in the form of trans-global politics vis-à-vis a state's commitment to achieving ethno-racial equality in the international arena. They test whether states that are highly committed at the international level are more willing to engage in ethnic enumeration at home than those who show little commitment, in part because ethnic enumeration is an indispensable tool for monitoring and addressing inequality. Secondly, they test the argument that state enumeration practices are shaped primarily by internal pressures and structural conditions, and specifically, that minority group claims and interests are influential in whether or not the state decides to recognize differences within its border (or not to recognize differences). As will be discussed in Part III, an underlying assumption of this perspective is that nominating groups into existence through enumeration is a matter of political negotiation, and not the objective assessment of internal diversity (Simon and Piché 2013). These hypotheses are tested with multivariate models based on a unique data set of national census questionnaires and population registration forms for over 200 countries, covering the period 1990-2006. Using information gathered from the website of the United Nations Committee on the Elimination of Racial Discrimination (CERD), and another dataset, Minorities at Risk (MAR), Kukutai and Thompson construct variables that capture internal and external pressures. The results show that not only the net effect (ceteris paribus) of internal factors but also the net effect of external factors play a significant role in whether or not states are involved in ethnic enumeration. 


\subsection{Enumeration and Identity Politics}

As Ann Morning has shown above, many countries have opted not to count populations based on ethnic or nationality criteria (in our typology, 'not counting for nation-building and assimilation'). The justifications are not all identical, but in all cases, ethnicity as a basis for social stratification is rejected, either in the name of national integration, as is presently the case in many African countries, or in the name of the principle of national unity, as is the case in several countries in Western Europe. The case of West Africa is particularly interesting insofar as ethnic analyses, which were omnipresent during the colonial period, have been abandoned in the postcolonial period in favour of a nation-building ideology. Indeed, they have moved from a situation in which ethnic classification, invented by colonial administrators and ethnologists (Amselle 1990: 22), was used as a basis for domination and distinction between populations to a situation in which the effort of developing and building a national identity was monopolized by the postcolonial state involved in a modernization process implying the disappearance of ethnic awareness (Otayek 2000: 87, 90). In this context, ethnic categorization became taboo owing to the weakness of the state trying to build a nation within borders drawn by the colonizers, borders that rarely took ethnic geography into consideration. For West Africa, analysis of ethnicity is all the more lacking as vast circular migratory movements have turned the region into an integrated economic space (Adepoju 1988:60; Cordell et al. 1996: 13). The concept of citizenship is of little importance in societies in which access to social security remains essentially within the family sphere and outside state-controlled legislation.

The refusal to include ethnic categories in official statistics characterizes nearly all the countries of Western Europe. According to a recent inventory, the reasons that these countries refuse to include questions regarding ethnic groups are mainly political, constitutional and legal: this is the case notably of France, Germany, Spain, Belgium, Denmark and Italy (Simon 2012). The case of France deserves particular attention insofar as the debates there are particularly virulent. Indeed, in France, the question of using ethnicity as an analytical or simply descriptive category is far from being resolved as is confirmed by debates that are ideological and controversial in nature (Lorcerie 1994; Blum and Guérin 2008; Simon 2008). This situation can be extended to most of western European countries where the absence of 'multicultural' traditions and the recent emergence of debates around ethnic and racial discriminations explain the absence of data on ethnic and racial categories. Furthermore, many objections, be they political or emanating from civil society, have recently arisen with respect to the relevance of collecting such data. Legislations and institutions dealing with data protection forbid, under certain conditions, the collection of sensitive data such as ethnic and racial origins (Ringelheim and De Schutter 2010).

Patrick Simon (Chap. 4) addresses specifically this public debate in France. In the first part of his chapter, he attempts to explain why there is resistance to collecting ethnic data. According to Simon, the framing offered by the French (republican) model of integration which promotes the invisibility of ethnic minorities and the 
rather recent emergence of debates around ethnic and racial discriminations explain the absence of data on ethnic and racial categories. In Belgium also, ethnicity remains taboo although, as we shall see in the next section, diversity is increasingly questioning the adequacy of the 'nationality' category for the study of ethnic relations. However, it is the French case that is mostly referred to as the example of fierce debates regarding the collecting of ethnic statistics. On the one hand, the republican paradigm, based on the assimilation model, posits that immigrants would (and should) lose their cultural and linguistic distinctiveness. Against this colour- or ethnicity-blindness, a competing approach argues for the need of ethnic data in order to study and monitor discrimination practices. Hence each model or paradigm calls for specific indicators: the assimilation perspective is satisfied with the three official categories (French, French by acquisition and foreigners), because they are geared to the study and monitoring of the assimilation of foreigners. Although the competing paradigm (anti-discrimination monitoring) has found its place since the end of the 1990s, the official approach remains republican for the time being.

In contrast to France, counting is considered crucial for certain countries, particularly when notions of survival and visibility are at the centre of identity politics. This situation prevails when numbers are significant in the balance of power relations. In this case, minority groups may find it useful to have access to statistical data, which document their fragile and precarious situation and allow them to make demands for a more equitable place in society.

The case of Quebec within Canada also illustrates the continuing debates about the nature of identity with respect to census categories. Ethnic studies have a longstanding history in Canada, upheld by ethnic statistics dating back to the nineteenth century (Beaud and Prevost 2008). For a long time, the study of ethnicity was based on the ethnic origin questions and was basically focused on French and English Canadian duality. Victor Piché's chapter presents an historical overview of how the changing nature of French-Québécois nationalism impacted on the choice of ethnic and linguistic indicators produced by the Canadian census (Chap. 5). For many years, there was a consensus on the choice of ethnic and linguistic indicators used for the monitoring of the French group in Quebec. Mother tongue and language spoken at home were two such indicators, in line with the prevailing ethnic nationalism and assimilation perspectives. However, with the important increase in ethnic diversity due to immigration, proponents of civic nationalism insisted on a more inclusive definition of identity and argued for indicators more in line with official policy geared towards integration into the use of the French language in the public sphere. This shift illustrates the close links between political discourse and ethnic and linguistic classifications. It also illustrates how ethnic data have been crucial in nationalist debates and the notion of ethnic survival.

The most compelling case for the production of racial and ethnic statistics has been the emergence of positive action policies and the concomitant demand for data for monitoring and evaluation purposes. All ideological constructions regarding notions of race and ethnicity are currently under pressure and being called into question. In particular, countries using statistical categories in order to dominate are being challenged by the minority rights movement and antiracist and 
anti-discriminatory ideologies. The recognition of pluralism is imposing an increasing number of new statistical practices and transforming the enumeration practices of censuses. This is particularly true in the case of Eastern Europe, where the issue of pluralism has appeared (Blum and Gousseff 1997; Abramson 2002; Arel 2002). Even countries such as France, which, as discussed above (Chap. 4), are characterized by the absence of ethnic statistics, are confronted by the increase in social demand for data requesting information concerning the integration of immigrants beyond the first generations (Simon 2008). Hence, a new issue is appearing in the countries of the European Union, supported by the Council of Europe, which expresses the need for reliable statistical data 'to encourage peaceful intercultural relations and ensure the protection of national minorities' (Haug 1998: 11; Mannila 2005).

Almost all chapters of the book deal directly or indirectly with this type of utilization of racial and ethnic data. Two chapters however deal explicitly with the positive action perspective. The Brazilian case discussed by José Luis Petrucelli is one of the most recent cases. The situation is characterized as presenting a persistent racial fragmentation, configuring it as a structural variable of its society, expressed in socioeconomic inequalities constantly observed by field research. In this sense, much information converges in showing the ethno-racial criterion as a decisive parameter of exclusion and of social subordination. Among the reasons for this reality, the permanence of several discriminatory practices in public and private institutions against the Africans and indigenous descending populations stands out (Telles 2006). The country can count on a reasonable tradition of statistical experience of racial classification (Loveman 2009). In this sense, two aspects are outlined: firstly, that the majority of Brazilians identifies with a restricted group of colour representation and second, that the spontaneous denominations and their relationship with the re-codified classic categories have shown a relatively temporal stability. But an important ambiguity persists in what concerns the pertinence of the category that accounts for the miscegenated groups at the national level and particularly in some areas of the country that have been, historically, less influenced in their population composition by the Atlantic slave traffic. Hence, it does have methodological pertinence to wonder about the best possibility of identifying the mentioned racial categories, which present temporal persistence and sociological consistence (Loveman et al. 2012).

The case of Great Britain is interesting because it clearly shows that the political use of ethnic and racial data can change over time. Debra Thompson (Chap. 7) argues that the British state has changed its approach to counting race over time. Using Rallu et al. (2006) typology, this chapter demonstrates that the British state has transitioned from not counting in the name of multiculturalism before and during the 1981 census to counting to justify positive action after the introduction of the ethnic question in 1991 and finally, counting in the name of multiculturalism with the modifications to the question in 2001. Hence, she argues that in a first phase, UK 'did not count' in the name of multiculturalism, based on two sets of arguments: it was considered impossible to define race and the question on race or colour would be perceived as offensive. On the other hand, there were considerable 
concerns that without such data, the seriousness of the government's commitment to ending racial discrimination in Great Britain would be undermined and a growing number of public bodies were thus advocating for the collection of racial statistics. But, conservatives campaigned against answering the question on race or ethnicity in the Census Test in 1979. Thus, there was sufficient opposition to exclude such questions in the 1981 census. One central argument refers to principles of neoconservative thought, concerned with the intrusion into the private affairs of individuals. ${ }^{2}$ With time the need for racial and ethnic data proved unsustainable, mostly from internal needs of the state bureaucracy. Once the production of ethnic data became officially acceptable, the next step involved negotiating the best definitions through a series of field tests. Ethnic minority organizations played an important role in these negotiations, particularly demands from Black and Asian groups for Black British and Asian British categories, indicating sensitivity to the race/citizenship nexus in Great Britain. In brief, the analysis of the political development of the ethnic question on the British census between 1981 and 2001 demonstrates that racial classifications are not simply the consequence of three often-posed drivers of census politics - demography, social mobilization and civil rights legislation - but rather are inherently connected to identity politics and debates over the nature of citizenship and belonging in a given country. These debates are partially informed by ideas about race, colour, ethnicity and difference, which are mitigated through the institutions of the state and are given administrative life and scientific legitimacy through the forum of the census (see also Aspinall 2012).

\subsection{Measurement Issues and Competing Claims}

The production of official ethnic and racial statistics is never unilateral, nor straightforward. On the contrary there are often competing paradigms, and policy outcomes are the result of contestations, negotiations and compromises (Simon and Piché 2013). Six case studies illustrate how measurement issues go beyond technical aspects and are confronted with contrasting approaches carried by different social groups within societies.

The chapter on Malaysia by Shyamala Nagaraj, Tey Nai Peng, Ng Chiu-Wan and Jean Pala (Chap. 8) illustrates how data on ethnicity are useful for the strengthening and monitoring of policies that seek to improve access to services in spheres such as employment, education and health. A great many of Malaysia's economic policies are linked to ethnicity, in order to reduce the imbalances that affect the Bumiputera community, which comprises mostly people of Malay origin but also some other minority groups accepted as 'sons of the soil'. The policy has seen some changes since the 1970s when it was first introduced, but it continues to be a powerful force

\footnotetext{
${ }^{2}$ Interestingly, the same type of argument has been used by the Canadian Conservative government to justify the elimination of the compelling aspect of the long census questionnaire dealing, among other things, with ethnic and racial questions.
} 
in the design and implementation of public policies. Malaysia has thus long been concerned with its many ethnic groups, be it in the political, economic or social arena. The counting of its major and minor groups has been an important function of the (usually) decennial census. Furthermore, information on ethnicity appears to be collected in almost all areas where documentation is involved whether in the public or private sector. But all this was possible because the Bumiputera groups were able to claim visibility due to ethnic revival brought about by the introduction of self-identification.

Uruguay, as analyzed by Cabella and Porzecanski (Chap. 9), presents a very different historical point of departure but ends up debating about what to do with diversity and discrimination. Historically, Uruguay has built upon what the authors call a national myth of racial democracy, homogeneity and equality of opportunities, all this based on the predominance of a population of European descent and the national state efforts of constructing a highly integrated society. Hence, referring to our typology, Uruguay was a country which 'did not count' for a long time. However, the country had to face increasing pressures exerted by Afro-Uruguayan organizations, which, in the end, contributed to the redefinition of Uruguayan identity. Furthermore, the myth of racial homogeneity was contradicted by a variety of social movements and ethnic leaders, based on studies showing empirically the significant socioeconomic gaps between Afro-descendants and Whites. In other words, the 'statistical' growth of the Afro-descendant and Indigenous populations during the last decades in Uruguay has fostered ethnic revival due to the increasing legitimacy of non-white identities as a means to combat discrimination. This process can be seen in most of Latin American countries, where an impressive upsurge of questions related to afro-descendent people had occurred in censuses in the last 30 years. In 1980 , only two countries were asking questions about race or colour, namely Brazil and Cuba; Colombia; Ecuador and El Salvador joined in during the 2000 census round, and to date, out of 18 countries which have conducted a census, 14 collect information on both indigenous people and afro-descendents (Cruces et al. 2012).

Like for other categories based on ethnicity, race or ancestry, the definition of Afro-descendent is not stabilized yet. The Working Group of Experts on People of African Descent ${ }^{3}$ has defined 'People of African Descent' as 'descendants of the African victims of the Trans-Atlantic and Mediterranean Sea slave trade' ${ }^{4}$ The chairperson of the working group adds in his report that 'for the definition to be completed, it must also include Africans and their descendants who, after their countries' independence emigrated to or went to work in Europe, Canada and the Middle East where they also experienced racial discrimination suffered by those who live in Western European countries'. ${ }^{5}$ This all-encompassing definition has taken different

\footnotetext{
${ }^{3}$ Established by the CHR resolution 2002/68.

${ }^{4}$ Identification and definition of 'People of African descent' and how racial discrimination against them is manifested in various region, Working Paper prepared by Ambassador P.L. Kasanda, Chairperson of the Working Group of Experts on People of African Descent, E/CN.4/2003/WG.20/ WP.3 28 January 2003.
}

${ }^{5}$ Op.cit. para 6. 
translation in Latin-American censuses in the 2010 round (Angosto Ferrandez and Kradolfer 2013).

The situation in Belgium is similar to the one described above for France. According to Nicolas Perrin, Luc Dal and Michel Poulain (Chap. 10), the ethnic reference has long been a taboo, particularly in the French-speaking region. Ideological debates, as in France, focus around the contention that origin-based statistics will foster the ethnicization of society, as opposed to arguments stating that current statistics do not provide an adequate portrait of the immigrant population. Indeed, there are growing pressures for taking into account discrimination, but existing official statistics on nationality are insufficient for that purpose. The intense immigration of the twentieth century is behind the emergence of a Belgian society profoundly marked by diversity. Until the 1980s, the distinction based on nationality was considered adequate to describe Belgian society characterized by a restrictive right to nationality. Multiple reforms in the Nationality Code adopted since 1984 have radically challenged this consensus. Today, Belgian society is progressively recognizing its ethnic diversity and the development of origin-based indicators from objective data such as nationality at birth or the country of birth of parents seems to be more and more accepted.

A number of chapters presented so far ask the question 'how different groups use census questions to redefine themselves'. Hence, different definitions of race and ethnicity will have important impacts on the size of different groups, thus addressing the issue of what is the correct definition. This is particularly true in the case of Indigenous populations. The next two chapters deal explicitly with this issue. In Olivier Barbary's chapter, two different criteria for defining the Indigenous population in Mexico produced 17 types of household, thus highlighting the high heterogeneity of the indigenous population (Chap. 11). Distinguishing among these different sub-groups is essential to capture the socio-economic differentiation between non-indigenous and indigenous households and among indigenous groups themselves. In this country, the census identification of Indigenous populations using linguistic criteria exists since the beginning of the twentieth century. However, with migration out of zones of origin and urbanization, the linguistic criterion is no longer appropriate inasmuch as it underestimates the importance of contemporary indigenous groups. The 2000 census thus included a self-declared ethnic identification. This chapter suggests a systematic approach to different statistical definitions, combining two dimensions: individual linguistic and self-declaration responses and household-level data linking individual responses to other household members. Multivariate analyses of the different groups based on the combined typology of households show that differences among indigenous groups and between them and non-indigenous groups are not only cultural but also based on differential access to economic resources.

The definition of Indigenous populations in Canadian censuses has always been fraught with great difficulties, particularly with respect to mixed origins. During the 1980s and 1990s, Aboriginal populations have experienced a demographic explosion. According to Eric Guimond, Norbert Robitaille and Sacha Senécal (Chap. 12), this can be accounted for by the phenomenon of ethnic mobility, i.e., changes in ethnic 
affiliation among individuals and families. This is particularly the case of intragenerational mobility (changes in the ethnic affiliation of a person over time). The authors note the same phenomenon for Aboriginal populations in the United States and Australia. They link these changes to social factors such as the restoration of Aboriginal people's pride. Territorial claim settlements and employment equity policies can also generate ethnic mobility.

\subsection{Conclusion}

If there were any beliefs that the production of census categories is objective and straightforward, the chapters presented here clearly show that racial and ethnic categories are social constructions embedded in historical and political dimensions of societies. To make a long story short, we argue that enumeration and identity politics are closely related, not only by the type of categorical identities that censuses display but also by those illegitimate identities that official statistics ignore. Furthermore, it is important to take into consideration competing claims when discussing racial and ethnic categorization and measurement issues in national censuses. On the one hand, it enables us to understand the history of ethnic and racial data production and use in a dynamic and contradictory way. On the other hand, it reminds us that the present cannot be taken for granted since competing claims and paradigms never disappear and the hegemony of one model can rapidly be questioned and inversions can occur depending on the force of specific political and social factors favouring one model over the other.

Canada illustrates, if need be, an unexpected historical case of inversion in the official production of ethnic data. We say 'unexpected' because Canada had always been pinpointed as an example of the consensual production of ethnic data. The fact is that a year ahead of the 2011 census, the government took an unforeseen decision to discard the mandatory full census form and to transfer all the questions to a non-mandatory household survey. This decision has fostered an unprecedented controversy on the risks of degrading the quality of the information gathered previously in the census. Technically, the non-response rate of a voluntary survey is obviously higher than for a compulsory census. Statistics Canada has assumed a response rate of $50 \%$ for the Household survey, to be compared with a $94 \%$ in the census. The agency tried to compensate for this reduction in the expected participation by increasing the sample size, so that the non-response bias will not affect the findings. Critical on the governmental decision, the head of Statistics Canada decided to resign from his mandate in protest, in July 2010.

The United States too have entered in a long process of revision of the statistical representation of race and ethnicity. After the introduction of a "Hispanic ethnicity" question in the census in 1970, the second major evolution of census classification occurred in 2000 with a multiple answer available to the race question. These evolutions came up as a combination of group negotiation (bottom-up) and state imposition (top-down) in the context of Civil Rights Movement and the shift in census understanding 
for the nation-state, government officials, interest groups and individuals (see Skrentny 2001). The census functions somehow as a mode of escaping oppression and the avenue for ethnic/racial groups to compete for a place within the larger nation-state, and ethnic and racial lobbying groups negotiate with special task forces within the Census Bureau gain recognition in official statistics (Schor 2009). In preparation of the next census in 2020, the Hispanic ethnicity and Race questions are under a new revision. The census bureau experiments different questions, wordings and coding to collect race and ethnicity (Compton et al. 2013). If retained after the National Content Test of 2015, the major change would consist in a combination of race and origin in a single question, with open ended questions for each ethnoracial category. Not only would the Hispanic question be conflated with the Race question, but the ethnic ancestry of (predominantly White) Americans would then be associated with their race. The introduction of a "MENA" category ("Middle Eastern or North African") in this redesigned ethnoracial question is also debated. This is a good example of the use of the census as a political forum to bringing about changes in collective representations and public policies (Prewitt 2013). In North America, like in all parts of the world, statistics tell a lot about how the State defines legitimate identities for the purpose of policy making and redistribution.

Open Access This chapter is distributed under the terms of the Creative Commons Attribution Noncommercial License, which permits any noncommercial use, distribution, and reproduction in any medium, provided the original author(s) and source are credited.

\section{References}

Abramson, D. (2002). Identity counts: The Soviet legacy and the census in Uzbekistan. In D. I. Kertzer \& D. Arel (Eds.), Census and identity: The politics of race, ethnicity, and language in national censuses (pp. 176-201). Cambridge: Cambridge University Press.

Adepoju, A. (1988). International migration in Africa south of the Sahara. In R. T. Appleyard (Ed.), International migration today (pp. 17-88). Paris: UNESCO.

Alonso, W., \& Starr, P. (Eds.). (1987). The politics of numbers. New York: Russell Sage.

Amselle, J.-L. (1990). Logiques métisses: Anthropologie de l'identité en Afrique et ailleurs. Paris: Payot.

Anderson, B. (1991). Imagined communities. New York: Verso.

Anderson, M., \& Fienberg, S. (1999). Who counts? The politics of census-taking in contemporary America. New York: Russell Sage.

Angosto Ferrandez, L. F., \& Kradolfer, S. (Eds.). (2013). Everlasting countdowns. Race, ethnicity and national censuses in Latin American States. Newcastle Upon Tyne: Cambridge Scholars Publishing.

Arel, D. (2002). Démographie et politique dans les premiers recensements post-soviétiques: Méfiance envers l'État, identités en question. Population, 57(6), 791-820.

Aspinall, P. (2012). Answer formats in British census and survey ethnicity questions: Does open response better capture "superdiversity"? Sociology, 46(2), 354-364.

Beaud, J.-P., \& Prevost, J.-G. (2008). La mesure de l'ethnicité au Canada. Tocqueville Review, 29(1), 73-92.

Blum, A., \& Gousseff, C. (1997). Nationalité, groupes ethniques, peuples: La représentation des nationalités en Russie. In J.-L. Rallu, Y. Courbage, \& V. Piché (Eds.), Old and new minorities/ Anciennes et nouvelles minorités (pp. 49-72). Paris: John Libbey \& INED. 
Blum, A., \& Guérin, F. (2008). From measuring integration to fighting discrimination: The Illusion of "Ethnic Statistics". French Politics, Culture \& Society, 26(1), 45-61.

Brubaker, R. (2009). Ethnicity, race, and nationalism. Annual Review of Sociology, 35, 21-42.

Compton, E., Bentley, M., Rastogi, S., \& Ennis, S. (2013). 2010 Census race and Hispanic origin alternative questionnaire experiment (2010 Census Planning Memoranda series, $\mathrm{n}^{\circ} 211$ ). Washington, DC: Bureau of the Census. https://www.census.gov/2010census/pdf/2010_ Census_Race_HO_AQE.pdf

Cordell, D., Gregory, J., \& Piché, V. (1996). Hoe and wage: A social history of a circular migration system in West Africa. Boulder: Westview Press.

Cruces, G., Garcia Domench, C., \& Pinto, F. (2012). Visibilidad estadistica: Datos sobre poblacion afrodescendiente en censos y encuestas de hogares de America Latina. Panama: Program Afrodescendant Population in Latin America II, UNDP.

Desrosières, A. (1993). La Politique des grands nombres. Histoire de la raison statistique. Paris: La Découverte.

Dieckhoff, A. (2000). La nation dans tous ses États. Paris: Flammarion.

Faist, T. (2009). Diversity - A new mode of incorporation? Ethnic and Racial Studies, 32(1), $171-190$.

Gellner, E. (1983). Nations and nationalism. Oxford: Basil Blackwell.

Haug, W. (1998). Introduction: La statistique des minorités prise entre la science et la politique. In W. Haug, Y. Courbage, \& P. Compton (Eds.), Les caractéristiques démographiques des minorités nationales dans certains États européens (pp. 11-26). Strasbourg: Council of Europe.

Hobsbawm, E. (1990). Nations and nationalism since 1780: Programme, myth, reality. Cambridge: Cambridge University Press.

Hobsbawm, E. (1993). Qu'est-ce qu'un conflit ethnique ? Actes de la Recherche en Sciences Sociales, 100, 51-57.

Kertzer, D. I., \& Arel, D. (Eds.). (2002). Census and identity. The politics of race, ethnicity and language in national censuses. Cambridge: Cambridge University Press.

Lorcerie, F. (1994). Les sciences sociales au service de l'identité nationale. Le débat sur l'intégration en France au début des années 1990. In D.-C. Martin (Ed.), Cartes d'identité. Comment dit-on "nous" en politique? (pp. 245-281). Paris: Presses de la FNSP.

Loveman, M. (2009). The race to progress: Census-taking and nation-making in Brazil (18701920). Hispanic American Historical Review, 89(3), 207-234.

Loveman, M., Muniz, J., \& Bailey, S. (2012). Brazil in black and white? Race categories, the census, and the study of inequality. Ethnic and Racial Studies, 35(8), 1466-1483.

Mannila, S. (Ed.). (2005). Data to promote equality: Proceedings of the European conference. Helsinki: Edita.

Nobles, M. (2000). Shades of citizenship: Race and the census in modern politics. Stanford: Stanford University Press.

Otayek, R. (2000). Identité et démocratie dans un monde global. Paris: Presses de Sciences Po.

Prewitt, K. (2013). What is your race? The flawed effort of the census to classify Americans. Princeton: Princeton University Press.

Rallu, J.-L., Piché, V., \& Simon, P. (2006). Demography and ethnicity: An ambiguous relationship. In G. Caselli, J. Vallin, \& G. Wunsch (Eds.), Demography: Analysis and synthesis. A treatise in population studies (Vol. 3, pp. 531-549). Burlington, MA: Elsevier Academic Press.

Ringelheim, J., \& De Schutter, O. (2010). Ethnic monitoring. The processing of racial and ethnic data in anti-discrimination policies: Reconciling the promotion of equality with privacy rights. Brussels: Bruylant.

Schor, P. (2009). Compte et classer: Histoire des recensements américains. Paris: Editions de l'EHESS.

Simon, P. (2005). The measurement of racial discrimination: The policy use of statistics. International Journal of Social Science, 183, 9-25.

Simon, P. (2008). The choice of ignorance: The debate on ethnic and racial statistics in France. French Politics Culture \& Society, 26(1), 7-31. 
Simon, P. (2012). Collecting ethnic statistics in Europe: A review. Ethnic and Racial Studies, 35(8), 1366-1391.

Simon, P., \& Piché, V. (Eds.). (2013). Accounting for ethnic and racial diversity: The challenge of enumeration. London: Routledge.

Skrentny, J. (Ed.). (2001). Color lines: Affirmative action, immigration and civil rights options for America. Chicago: University of Chicago Press.

Szreter, S., Sholkamy, H., \& Dharmalingam, A. (Eds.). (2004). Categories and contexts: Anthropological and historical studies in critical demography. Oxford: Oxford University Press.

Telles, E. (2006). Race in another America: The significance of skin color in Brazil. Princeton: Princeton University Press.

Williams, M. \& Husk, K. (2012). Can we, should we, measure ethnicity?. International Journal of Social Research Methodology (On Line).

Zuberi, T. (2001). Thicker than blood: How racial statistics lie. Minneapolis/London: University of Minnesota Press. 